\title{
MOLECULAR INSIGHT ON PHYLOGENY AND SYSTEMATICS OF THE LOPHOZIACEAE, SCAPANIACEAE, GYMNOMITRIACEAE AND JUNGERMANNIACEAE
}

\author{
ФИЛОГЕНИЯ И СИСТЕМАТИКА LOРНОZIAСЕАЕ, SCAРАNIACЕАЕ, \\ GYMNOMITRIACEAE И JUNGERMANNIACEAE С ПОЗИЦИИ \\ МОЛЕКУЛЯРНОЙ ФИЛОГЕНЕТИКИ
}

\author{
A.A. ViLnET ${ }^{1}$, N.A. KONSTANTINOVA ${ }^{1} \&$ A.V. TROITSKY ${ }^{2}$ \\ А.А. ВИЛЬНЕТ ${ }^{1}$, Н.А. КОНСТАНТИНОВА ${ }^{1}$, А.В. ТРОИЦКИЙ ${ }^{2}$
}

Abstract

The aim of the study is an expanded molecular phylogenetic analysis of the Holarctic taxa traditionally classified to the families Lophoziaceae, Scapaniaceae, Gymnomitriaceae and Jungermanniaceae. Also we will provide a justification of some nomenclatural changes suggested recently by Konstantinova \& Vilnet (2009). The nuclear ITS1-2 and chloroplast trnL-F DNA sequences of 134 taxa (189 samples) from suborders Jungermanniineae and Cephaloziineae were analyzed. The topologies of phylogenetic trees constructed from combined sequences by maximum parsimony and Bayesian methods are congruent. The separation of family Diplophyllaceae from Scapaniaceae is not supported. The recently described family Solenostomataceae appears to be paraphyletic: the genus Nardia is in a sister relation to Gymnomitriaceae. The inclusion of the genus Isopaches in the family Anastrophyllaceae is questionable. Position of Obtusifolium and Protolophozia elongata in Scapaniaceae is not strongly supported. Phylogenetic relations within the genus Scapania are not fully resolved, but monophyly of sections Undulatae and Calcicolae is supported. Species assigned by some authors to a separate genus Scapaniella are scattered in different clades of the genus Scapania. Macrodiplophyllum imbricatum and M. plicatum can either be treated as Douinia or all these taxa included in Scapania. The distribution of species from the family Gymnomitriaceae on phylogenetic trees is congruent with the level of development or reduction of the perianth and perigynium. Taxonomically the species of Marsupella with reduced perianth are referred to Gymnomitrion, whereas the species called G. apiculatum that has a distinct perianth is transferred to Marsupella. The species status for Scapania tundrae, S. paludosa, S. crassiretis and Marsupella aquatica is supported. Genera Lophozia s.str., Schistochilopsis, Tritomaria, Protolophozia, Orthocaulis and Crossogyna are polyphyletic. The data support segregation of the recently described genera Pseudotritomaria, Heterogemma, Lophoziopsis, Pseudolophozia, Schljakovianthus, Schljakovia and Biantheridion.

Резюме

Целью данной работы является расширение представлений о молекулярной филогении и систематике наиболее крупных Голарктических таксонов печеночников, традиционно относимых к семействам Lophoziaceae, Scapani-

1 - Polar-alpine Botanical Garden-Institute of Kola SC RAS, Kirovsk, 184236 Russia - Россия 184236, Кировск, Полярно-альпийский ботанический сад-институт Кольского НЦ PAH; e-mail: anya_v@list.ru, nadya50@list.ru

2 - A. N. Belozersky Institute of Physicochemical Biology, Moscow State University, Moscow, 119991, Russia - Россия, 119991, Москва, Московский государственный университет, Институт физико-химической биологии им. А.Н. Белозерского; tav@genebee.msu.su 
aceae, Gymnomitriaceae и Jungermanniaceae. В работе приводится обоснование некоторых таксономических изменений, опубликованных ранее (Konstantinova \& Vilnet, 2009). Нами проанализированы последовательности ITS1-2 ядДНК и $\operatorname{trnL}-\mathrm{F}$ хпДНК 134 видов и внутривидовых таксонов печеночников, представленных 189 образцами, из подпорядков Jungermanniineae и Cephaloziineae. Топологии филогенетических деревьев, построенных по комбинированной матрице последовательностей методом максимальной экономии и методом Байеса, во многом сходны. Выделение семейства Diplophyllaceae из Scapaniaceae нецелесообразно. Недавно описанное семейство Solenostomataceae полифилетично: род Nardia формирует кладу, сестринскую семейству Gymnomitriaceae. Включение рода Isopaches в семейство Anastrophyllaceae не нашло твердой поддержки, так же как положение Obtusifolium и Protolophozia elongata в семействе Scapaniaceae. Филогенетические связи в роде Scapania выявлены не четко, однако поддержано выделение секций Undulatae и Calcicolae. Виды рода Scapaniella локализованы в разных кладах рода Scapania и не обособлены от него. Macrodiplophyllum imbricatum и M. plicatum могут быть отнесены к роду Douinia, либо все эти таксоны следует включить в Scapania. Распределение видов из семейства Gymnomitriaceae на филогенетических деревьях согласуется с признаком развития или редукции периантия и перигиния. Таксономически виды рода Marsupella с редуцированным периантием отнесены к роду Gymnomitrion, в то время как вид, традиционно относившийся к последнему роду, G. apiculatum, характеризующийся развитым периантием - к Marsupella. Роды Lophozia s.str., Schistochilopsis, Tritomaria, Protolophozia, Orthocaulis и Crossogyna полифилетичны. Полученные данные подтверждают целесообразность выделения новых родов Pseudotritomaria, Heterogemma, Lophoziopsis, Pseudolophozia, Schljakovianthus, Schljakovia и Biantheridion. Видовой статус Scapania tundrae, S. paludosa, S. crassiretis и Marsupella aquatica поддержан.

KEYWORDS: Hepaticae, Jungermanniales, ITS1-2, molecular phylogeny, trnL-F

\section{INTRODUCTION}

Families Scapaniaceae Mig., Gymnomitriaceae H. Klinggr. and Jungermanniaceae Reichenb. (including Lophoziaceae Cavers) were for a long time treated in suborder Jungermanniineae R.M. Schust. (Schuster, 1984). However Schuster (1966) wrote, "the suborder Jungermanniineae is the most difficult of the groups of Jungermanniales $\mathrm{H}$. Klinggr. to circumscribe, perhaps because it is "still heterogeneous". One of the largest families, Lophoziaceae, was distinguished as a distinct one by Schuster (1969), Kitagawa (1965, 1966), Schljakov (1980) and Grolle \& Long (2000) or it was included in Jungermanniaceae (Schuster, 1984; Grolle, 1983). Results of modern molecular phylogenetic studies were mainly unexpected but allowed to clarify relation within this group. Both suborder Jungermanniineae sensu Schuster (1984) and many families and genera were shown to be polyphyletic (Davis, 2004; Yatsentyuk et al., 2004; Heinrichs et al., 2005;
Forrest et al., 2006; He-Nygren et al., 2006; Hentschel et al., 2007). Taxa that were previously treated in the family Jungermanniaceae, are classified now in suborders Jungermanniineae and Cephaloziineae Schljakov (Crandall-Stotler et al., 2009).

Solenostoma Mitt., Plectocolea (Mitt.) Mitt. and Nardia Gray were excluded from the Jungermanniaceae s. str. and combined in a new family Solenostomataceae Stotler \& Crand.-Stotl. in suborder Jungermanniineae (Crandall-Stotler et al., 2009). Heinrichs et al. (2005) suggested to include family Lophoziaceae into Scapaniaceae and He-Nygren et al. (2006) transferred the latter taxon into suborder Cephaloziineae. The genus Jamesoniella (Spruce) F. Lees s. lat. was transferred from Jungermanniaceae to the Jamesoniellaceae (He-Nygren et al., 2006) or to the Adelanthaceae (Joerg) Grolle subfam. Jamesonielloideae (De Roo et al., 2007) that was placed in suborder Cephaloziineae. 
The inclusion of Lophoziaceae into Scapaniaceae (Heinrichs et al., 2005) was questionable due to only Lophozia (Dumort.) Dumort. s. str., Tritomaria Loeske, Saccobasis H. Buch and Schistochilopsis (Kitag.) Konstant. were clustered with Scapaniaceae, whereas other genera composed a robust clade (Vilnet et al., 2009a) that was described as a separate family Anastrophyllaceae L. Söderstr., De Roo \& Hedd. (Söderström et al., 2010).

It was shown that chloroplast trnL-F sequence data on Lophozia, Anastrophyllum (Spruce) Steph. and Jungermannia L. support the narrow generic concept (Yatsentyuk et al., 2004). Nevertheless, some genera, for example, Lophozia s.str., Schistochilopsis, Tritomaria, etc. even in narrow sense (Buch, 1933; Schljakov, 1980) appear to be polyphyletic (De Roo et al., 2007; Vilnet et al., 2009a).

In this paper we discuss taxonomic rearrangements within the largest boreal hepatic families basing on analysis of nuclear ITS1-2 and chloroplastic trnL-F sequences. The present set of taxa is expanded comparatively with the previous analysis being enlarged by a number of taxa and samples that include recently described and rare arctic species.

\section{MATERIAL AND METHODS}

\section{Taxa}

The ITS1-2 nrDNA and trnL-F cpDNA sequences of 134 taxa (189 samples) of jungermaniioid liverworts were analyzed (Table 1). Many species were represented by two specimens collected mainly in geographically distant regions.

DNA isolation, amplification and sequencing

DNA was extracted from dried liverwort tissues using the NucleoSpin Plant Kit (MachereyNagel, Germany). The trnL-F region of the chloroplast genome, including the part of the 5'-terminal exon, intron, the 3 '-terminal exon of the $\operatorname{trn} \mathrm{L}$ gene, the $\operatorname{trn} \mathrm{L}-\mathrm{F}$ intergenic spacer and part of the $\operatorname{trn} \mathrm{F}$ gene, was amplified and sequenced using primers suggested by Taberlet et al. (1991). The ITS1-2 region of the nuclear genome containing part of the 26S rDNA gene, ITS1, 5,8S rDNA gene, ITS2 and part of the 18S rDNA gene was amplified and sequenced using pairs of external and internal primers (White et al., 1990).

PCR were carried out in $20 \mathrm{mkl}$ volumes ac- cording to the following procedure: $3 \mathrm{~min}$ at $94^{\circ} \mathrm{C}$, 30 cycles $\left(30 \mathrm{~s} 94^{\circ} \mathrm{C}, 40 \mathrm{~s} 58^{\circ} \mathrm{C}, 60 \mathrm{~s} 72^{\circ} \mathrm{C}\right)$ and 2 min of extension time at $72^{\circ} \mathrm{C}$. Amplified fragments were visualized on $1 \%$ agarose TAE gels by EthBr staining, purified using the $\mathrm{GFX}^{\mathrm{TM}} \mathrm{PCR}$ DNA and Gel Band Purification Kit (Amersham Biosciences, U.S.A.), and then used as a template in sequencing reactions with the ABI Prism BigDye Terminator Cycle Sequencing Ready Reaction Kit (Applied Biosystems, USA) following the standard protocol provided for 3100 Avant Genetic Analyzer (Applied Biosystems, USA). GenBank accession numbers are in Table 1.

\section{Phylogenetic analyses}

Phylogenetic reconstructions are based on the combined ITS1-2 and trnL-F data. Combined sequences for Lophoziopsis (Lophozia) polaris, Lophozia silvicola, L. silvicoloides (Spitsbergen), Obtusifolium obtusum, Douinia ovata are derived from two specimens of each (cf. Table 1). Nucleotide data for both samples of Schistochilopsis incisa include the trn L-F sequences only. The ITS1-2 of Heterogemma (Schistochilopsis) laxa and Scapania tundrae are presented by two partitions ITS1 and 5.8SrDNA-ITS2, sequenced from one sample. The sequences were aligned manually using the BioEdit program (Hall, 1999). All positions of alignment were included in the phylogenetic analyses.

Two analytical procedures were implemented for the analyses: a maximum parsimony method (MP) with the TNT program (Goloboff et al., 2003) and Bayesian method with the MrBayes v 3.1.2. (Ronquist \& Huelsenbeck, 2003). In both cases Herbertus dicranus was used as an outgroup. The parsimony analysis with TNT involved a New Technology Search with search minimal length tree by five reiterations and 1000 bootstrap resamplings, for other parameters the default setting was used. Gaps were treated as missing data, indels were taken into account by a modified complex coding algorithm in SeqState (Müller, 2005).

For Bayesian (BA) analysis initially a best-fit evolutionary model of nucleotide substitutions was determined using the Modelgenerator software (Keane et al., 2004). The general time-reversible model with invariable sites and a gammadistributed rate heterogeneity parameter 


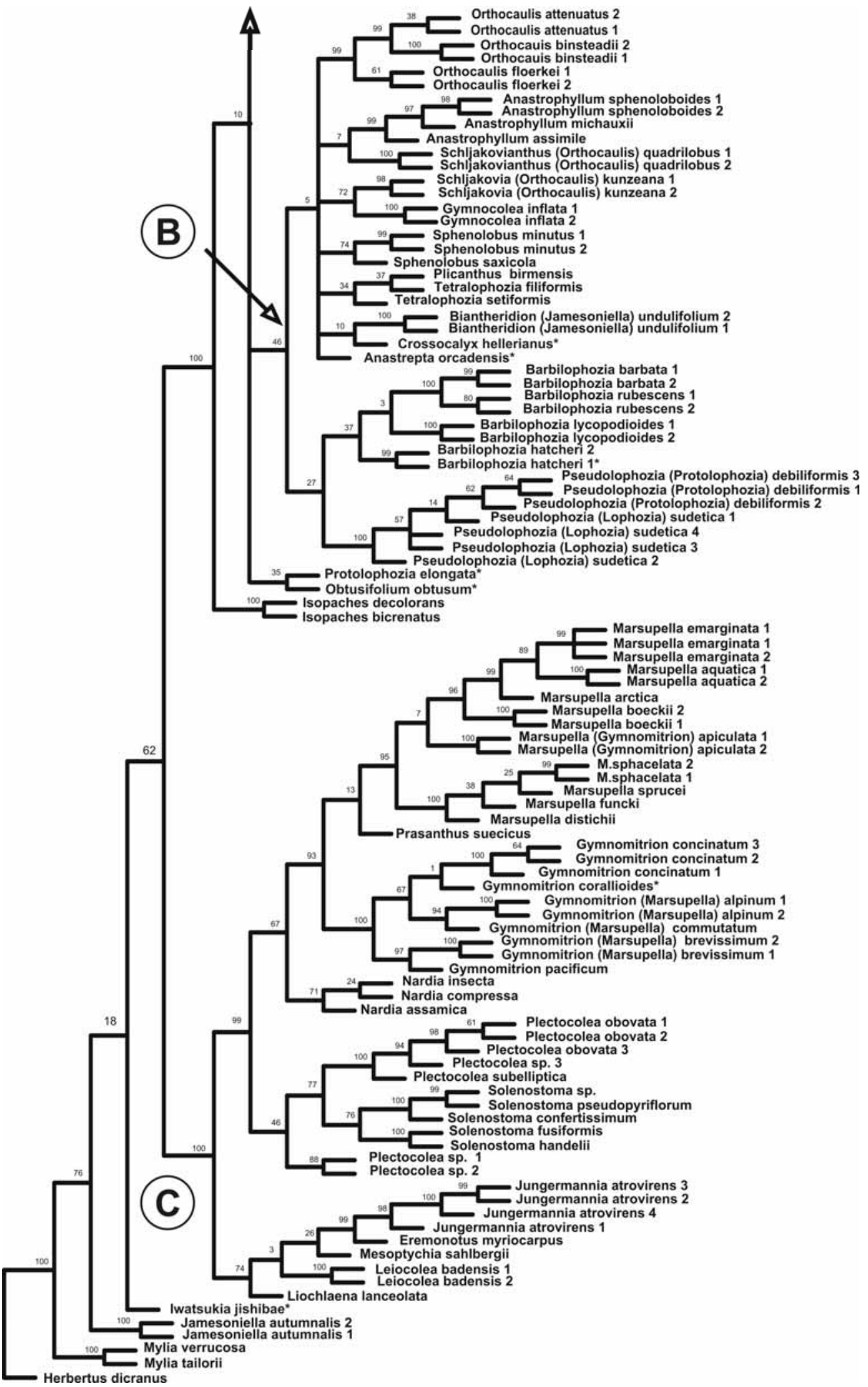


Fig. 1. Maximum parsimony (MP) phylogenetic tree for Jungermanniineae and Cephaloziineae, based on combined nucleotide sequences of ITS1-2 nrDNA and trnL-F cpDNA. Bootstrap support values are indicated. Taxa with different position on MP and BA trees are marked by asterisk.
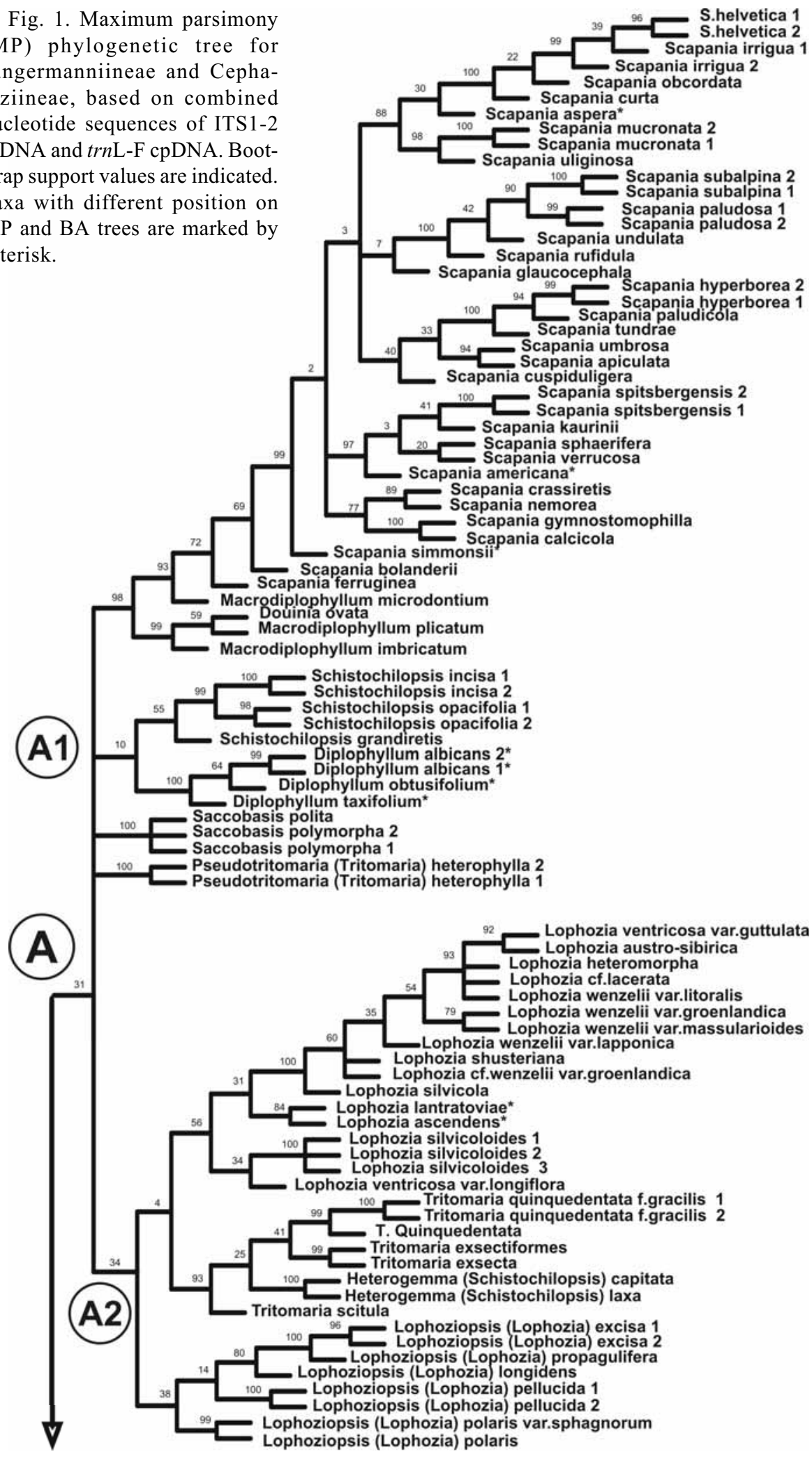


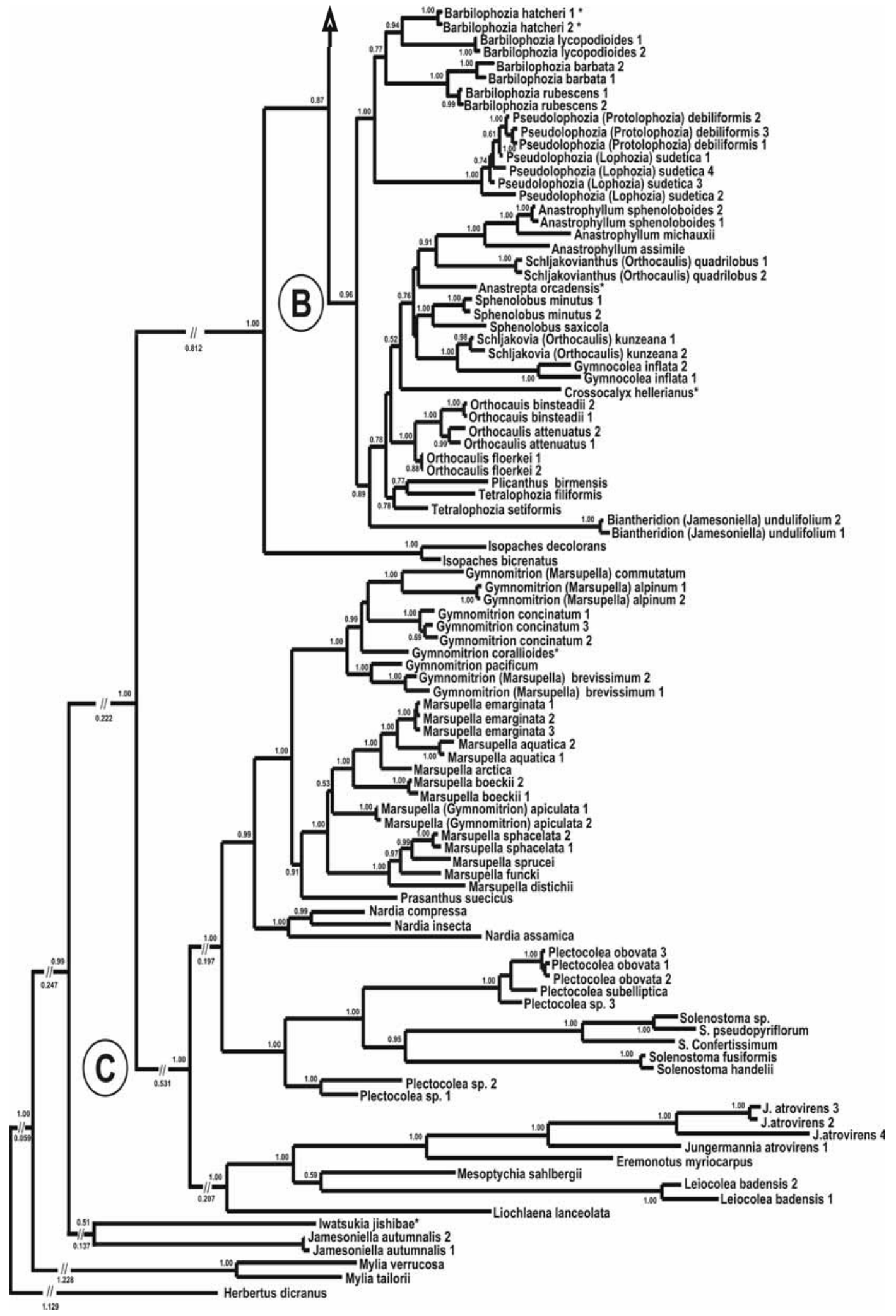




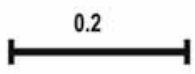

Fig. 2. Phylogenetic tree for Jungermanniineae and Cephaloziineae, based on combined nucleotide sequences of ITS1-2 nrDNA and trnL-F cpDNA by the Bayesian approach (BA). The Bayesian posterior probabilities are indicated. Taxa with different position on MP and BA trees are marked by asterisk.

Scapania helvetica 1 Scapania helvetica 2 0.99 -Scapania irrigua 1 Scapania irrigua 2
Scapania obcordata Scapania curta

1.00 - Scapaniania uliginosa Scapania mucronata 2
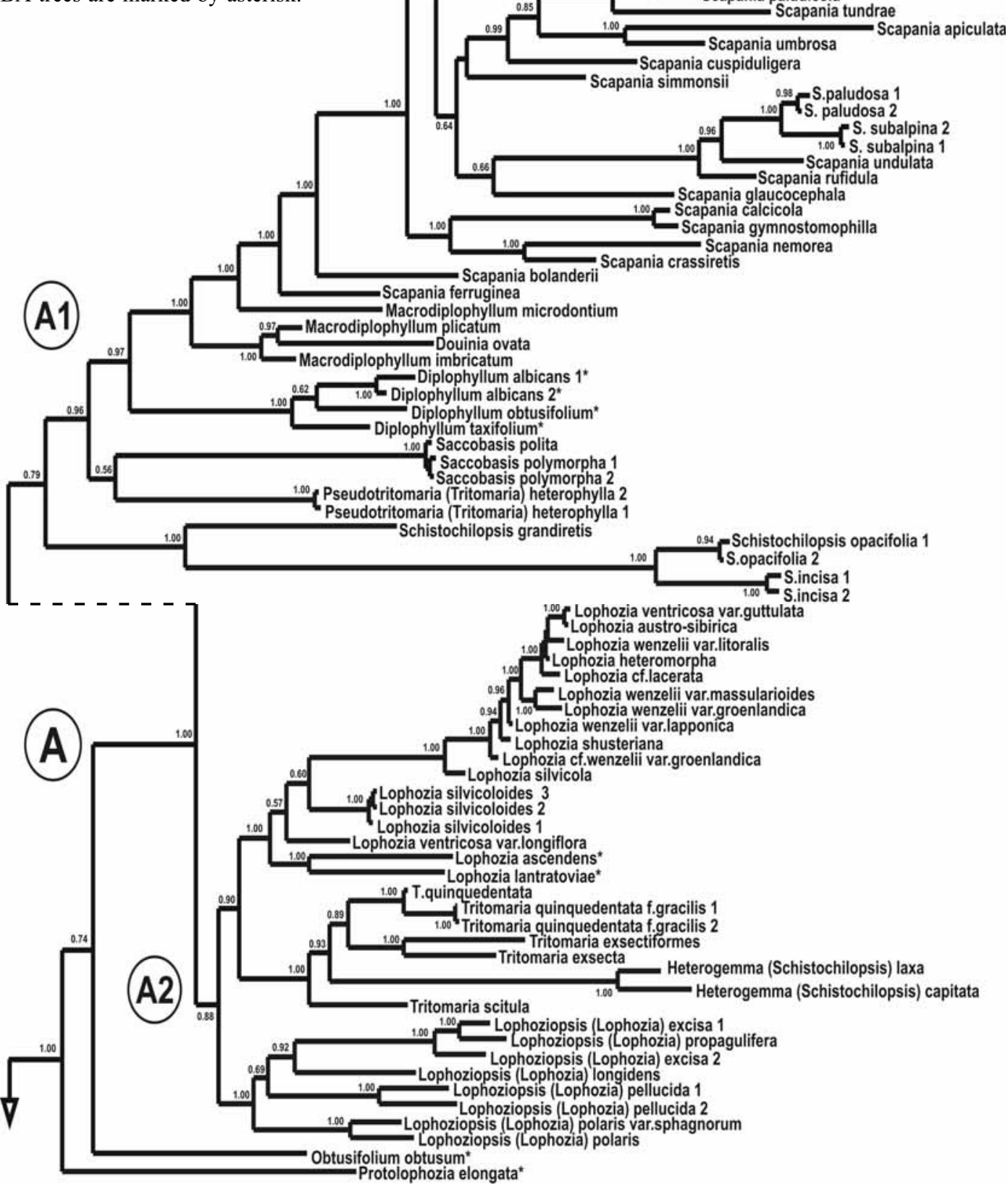
$(\mathrm{GTR}+\mathrm{G}+\mathrm{I})$ was selected. Sequence alignment was divided into six partitions: $5.8 \mathrm{~S}$ plus trnF, ITS1, ITS2, trnL 5'-terminal exon plus trnL 3'terminal exon, $\operatorname{trn} \mathrm{L}$ intron and $\operatorname{trn} \mathrm{L}-\mathrm{F}$ spacer. Each of these partitions was separately assigned the $\mathrm{GTR}+\mathrm{G}+\mathrm{I}$ model, gamma distributions were approximated using four categories. Two independent runs of the Metropolis-coupled MCMC were used to sample parameter values in proportion to their posterior probability. Each run includes three heated chains and one unheated, and two starting trees were chosen randomly. The number of generations was $10,000,000$, and trees were saved once every 100 generations. The first 25000 trees were discarded in each run, and 15000 trees from both runs were sampled after burning. Bayesian posterior probabilities were calculated as branch support values. The genetic p-distances referred anywhere in a text below calculated by MEGA 3.1 (Kumar et al., 2004) (see supplement at the electronic version on www.arctoa.ru).

\section{RESULTS}

ITS1-2 sequences for 147 samples and trnLF sequences for 129 samples were determined in this study. Additionally, 41 sequences of ITS1-2 and 61 sequences of trnL-F were taken from previous studies (Yatsentyuk et al., 2004; Vilnet at al., 2007a; Vilnet at al., 2008). The ITS1-2 alignment consists of 1365 positions. Among them, $787(57.7 \%)$ are variable and $644(47.2 \%)$ are parsimony informative. The trnL-F alignment consists of 660 sites, the $335(50.8 \%)$ positions are variable and $260(39.4 \%)$ are parsimony informative. The entire alignment of 189 sequences consists of 2025 sites that were included in the analyses. There are 1122 (55.4\%) characters that are variable, and 904 (44.1\%) are parsimony informative. In the MP analysis the alignment contained 78 additional indel coded positions.

The MP analysis with TNT yielded from 11 to 20 equally parsimonious trees at different runs with a length of 6076 steps, the tree resulted after 1000 bootstrap resamplings with indicated bootstrap support values (BS) is shown in Fig. 1.

In the BA analysis, trees were sampled after reaching stationarity; average standard deviation of split frequencies between two runs was 0.008618 . Arithmetic means of Log likelihoods for runs sam- pled were -30551.73 and $-30534.00 .95 \%$ and $99 \%$ credible sets contain 64794 and 70794 trees, respectively. The BA tree with means of posterior probabilities (PP) is presented in Fig. 2.

The topologies of MP and BA trees are in a good agreement. The discrepancies are caused by unresolving of some groupings in MP tree (see below) and by low supports in MP tree positions of some species inside highly supported clades. Taxa with different position in MP and BA trees are marked by asterisk in Figs. 1-2. Three main clades $\mathrm{A}, \mathrm{B}$ and $\mathrm{C}$ are found in both analyses (Figs. 1-2). Clade A (BS=31, $\mathrm{PP}=1.00)$ is subdivided into subclades $\mathrm{A} 1$ and $\mathrm{A} 2$ in $\mathrm{BA}$ tree (Fig. 2), while A1 is partly presented as an unresolved polytomy in MP tree (Fig.1). Family Scapaniaceae in its traditional circumscription is resolved as a monophyletic group, A1, with $\mathrm{PP}=0.97$ in the BA analysis (Fig. 2), whereas in MP tree the genus Diplophyllum (Dumort.) Dumort. is segregated in unsupported clade with Schistochilopsis section Incisae (C.E.O. Jensen) Potemkin (Fig. 1). The latter taxon composes a small clade sister to the rest of A1 subclade in BA tree (Fig. 2). The genus Saccobasis and Pseudotritomaria (Tritomaria) heterophyl$l a$, traditionally assigned to the family Lophoziaceae, either form separate branches within unresolved polytomy in A-clade in the MP tree (Fig.1), or compose a low supported clade $(\mathrm{PP}=0.56)$ in the BA tree (Fig. 2). The genera Lophozia, Lophoziopsis, Tritomaria and Heterogemma compose the second subclade, A2 $(\mathrm{BS}=34, \mathrm{PP}=0.88)$.

Other taxa refered usually to Lophoziaceae (excluding Leiocolea (Müll. Frib.) H. Buch) compose clade $\mathrm{B}(\mathrm{PP}=0.96)$ with two subclades. The first subclade, $\mathrm{B} 1(\mathrm{PP}=1.0)$ contains Barbilophozia Loeske, Pseudolophozia (Protolophozia) debiliformis and P. (Lophozia) sudetica, and the second subclade, B2 ( $\mathrm{PP}=0.89)$ includes Anastrophyllum s.1., Gymnocolea Dumort., Anastrepta (Lindb.) Schiffn., Orthocaulus H. Buch, Schljakovia Konstant. \& Vilnet, Schljakovianthus Konstant. \& Vilnet, Biantheridion (Grolle) Konstant. \& Vilnet, Tetralophozia (R.M. Schust.) Schljakov, Plicanthus R.M. Schust.

Three genera of Gymnomitriaceae studied here compose a robust subclade in the clade $\mathrm{C}$ 
$(\mathrm{BS}=93, \mathrm{PP}=1.0)$ sister to taxa traditionally placed to Jungermanniaceae s.str. The genera Gymnomitrion Corda and Marsupella Dumort. are resolved as not monophyletic, but composing of two intermingled subclades. The family Jugermanniaceae s.str. is found to be polyphyletic: Nardia is a sister to the Gymnomitriaceae (BS=67, PP=0.99), while Solenostoma and Plectocolea form a clade $(\mathrm{BS}=46, \mathrm{PP}=1.00)$. The close relationship of Mesoptychia (Lindb.) A. Evans., Eremonotus Lindb. \& Kaal. ex Pearson, Liochlaena Nees and Leiocolea to Jungermannia s. str. is evident in both obtained topologies $(\mathrm{BS}=74, \mathrm{PP}=1.00)$. The genus Mylia Gray has a basal position in both trees.

Protolophozia elongata and Obtusifolium obtusum are located as two separate lineages at the base of clade $\mathrm{A}$ in the $\mathrm{BA}$ tree (with $\mathrm{PP}=1$ and $\mathrm{PP}=0.74$ consequently) or form a weekly supported clade $(\mathrm{BS}=35)$ in unresolved relation to clade $\mathrm{A}$ and $\mathrm{B}$ in the MP tree.

\section{DISCUSSION}

The obtained results allow to modify the latest classification of the Jungermanniales (CrandallStotler et al., 2009), by including in the analysis many additional northern taxa and samples. There are two main clades within Scapaniaceae (including Lophoziaceae) that allow us to recognize two families, Scapaniaceae and recently discribed Anastrophyllaceae (Söderström et al., 2010) opposite to Scapaniaceae sensu Heinrichs et al. (2005). The family Solenostomataceae with inclusion of Nardia (Crandall-Stotler et al., 2009) is not supported by topologies obtained here. In our analysis, the genera Lophozia s.str., Schistochilopsis, Tritomaria, Protolophozia, Orthocaulis, Gymnomitrion, Marsupella, and Crossogyna are found to be polyphyletic, which resulted in a segregation some new genera (Konstantinova \& Vilnet, 2009). We understand that the taxa sampling for some genera is still insufficient, especially for those occurred mainly in South Hemisphere, so only a more reliable results are discussed below.

\section{Clade $A$}

Clade A embraces species of traditionally circumscribed Scapaniaceae and several genera of Lophoziaceae, particularly Tritomaria, Pseudotritomaria, Saccobasis, Schistochilopsis, Heterogemma, Lophozia and Lophoziopsis ( $\mathrm{PP}=1)$. It is divided into subclades $\mathrm{A} 1$ ( $\mathrm{PP}=0.97$, Fig. 2) and $\mathrm{A} 2(\mathrm{PP}=0.88)$. In MP tree subclade A1 is represented by four separate linages (Fig. 1). Similar taxa relation was found earlier by De Roo et al. (2007) and mainly agree with a new circumscription of the family Scapaniaceae suggested by Söderström et al. (2010).

The two genera in their former broader circumspriptions, Tritomatia and Schistochilopsis, are distributed among both subclades A1 and A2, which suggest to split them. So now Pseudotrotomaria (Tritomaria) heterophylla specimens form a branch in A1, while all other Tritomaria species form a clade (with nested Heterogemma (Schistochilopsis) capitata and H. laxa, see below) in subclade A2. The genus Saccobasis that had been treated as subgenus of Tritomaria by many authors (Schuster, 1969; Grolle \& Long, 2000; Damsholt, 2002; Schumacker \& Váňa, 2005; etc.) is located in a separate branch in A1 in MP (Fig. 1) or combined in a clade $(\mathrm{PP}=0.56)$ with Pseudotrotomaria (Tritomaria) heterophylla in BA (Fig. 2). Close affinity of the latter taxon to Saccobasis was suggested by Schuster (1969: p.695), however they have a number of important differences in mophology: Pseudotritomaria (Tritomaria) heterophylla differs from Saccobasis (1) by simply transversly inserted leaves versus leaves attached by a complex and sinuous line slightly decurrent both antically and postically in Saccobasis; (2) constant presence of red-brown or purplish stellate gemmae versus absent or rare ellipsoidal gemmae in Saccobasis; (3) short dentate perianth mouth versus entire one in Saccobasis. Also Pseudotritomaria differs from both Saccobasis and Tritomaria in spinose-dentate to ciliate-dentate margins of lobes of female bracts (edentate in Saccobasis and Tritomaria) and often apiculate or cuspidate lobes of leaves versus obtuse in Saccobasis and obtuse to subacute or acute in Tritomaria. Taking into account the position in phylogenetic trees, relatively high values of genetic distances (see supplement at the electronic version on www.arctoa.ru) between Saccobasis and other Tritomaria species counted by studied DNA loci and quite distinct morphological features some of which were men- 
tioned above we have proposed to segregate $T$. heterophylla in a monotypic genus Pseudotritomaria Konstant. \& Vilnet (Konstantinova \& Vilnet, 2009).

The section Incisae of the genus Schistochilopsis is located in A1 subclade, while $S$. capitata and S. laxa from the section Heterogem$m a$ are nested within Tritomaria in A2 subclade (Figs. 1-2). The morphological differences between both Schistochilopsis sections were discussed in Vilnet et al. (2008), and later Heterogemma (Joerg.) Konstant. \& Vilnet was rised to generic rank (Konstantinova \& Vilnet, 2009). According to our unpublished data, the $\operatorname{trn} \mathrm{L}-\mathrm{F}$ sequences of $S$. cornuta (Steph.) Konstant., the type species of the genus Schistochilopsis, is highly similar to species of the section Incisae, so the latter should be kept in this genus.

\section{Subclade A1}

Majority of taxa in subclade A1 belongs to the former Scapaniaceae. The ITS1-2 and trnLF sequences from 30 species of Scapania (Dumort.) Dumort. reveal that their distribution in the clades corresponds partially to the subdivision of the genus based on morphological data, but, as a whole, phylogenetic relation within Scapania stays unclear due to the dubious position of some clades on the trees (Fig. 1-2).

Scapania undulata, S. paludosa, S. subalpina, $S$. rufidula compose a robust clade $(\mathrm{BS}=100$, $\mathrm{PP}=1.00$ ) that agrees with the section Undulatae sensu H. Buch (1928). Thus, the separation of $S$. rufidula in section Rufidula together with $S$. spitsbergensis by Schuster (1974) is not supported.

Scapania calcicola and $S$. gymnostomophila form a clade $(\mathrm{BS}=100, \mathrm{PP}=1.00)$ that corresponds to section Calcicolae Müll. Frib. ex R.M. Schust. as it was circumscribed by Potemkin (2002).

All species from the commonly recognized section Irrigua (Müll. Frib.) H. Buch (S. hyperborea, S. paludicola, S. tundrae) (Arnell, 1956; Schuster, 1974; Grolle \& Long, 2000; Schljakov, 1981), except the type species, $S$. irrigua, were found in one clade $(\mathrm{BS}=100$, $\mathrm{PP}=1.00)$. Scapania irrigua was combined with species from section Curtae sensu Potemkin (2002) i.e. S. curta, S. obcordata, S. helvetica, $S$. mucronata, although without a high support $(\mathrm{BS}=88, \mathrm{PP}=0.85)$. This arrangement never had been assumed before. Differences between nucleotide sequences of $S$. irrigua and $S$. helveti$c a$ include a single substitution in ITS1 and one indel of one nucleotide that corresponds to a level of infraspecific variability in both species. The affinity of S. uliginosa to S. mucronata revealed in our analysis $(\mathrm{BS}=98, \mathrm{PP}=1.00)$ is unexpected because their morphology as well as ecology are quite distinct. It is worth to note however, that genetic distance between these species is rather high.

Scapania kaurinii, S. sphaerifera and $S$. verrucosa were classified variously by different authors and even were segregated in monotypic sections by Potemkin (2002). In our analysis they compose a clade with $S$. americana and $S$. spitsbergensis with high support $(\mathrm{BS}=97, \mathrm{PP}=1.00)$.

Scapania apiculata and S. glaucocephala, classified as a subgenus by Schuster (1974) or genus Scapaniella by Buch (1928), were found in different subclades, so they are likely not closely related and should not be considered as congeneric (cf. Crandall-Stotler et al., 2009).

Three morphologically similar pairs of species, Scapania hyperborea and $S$. tundrae, $S$. paludosa and $S$. uliginosa, $S$. crassiretis and $S$. nemorea, sometimes treated as conspecific (e.g. Potemkin, 1994; 1999a) are clearly separated genetically (Vilnet et al., 2006). Nucleotide sequence data confirm these taxa as distinct species, as was suggested by Buch (1928).

Previous molecular analyses did not clarify the relationships of Diplophyllum, Macrodiplophyllum (H. Buch.) Perss. and Douinia H. Buch (Schill et al., 2004; Yatsentyuk et al., 2004; De Roo et al., 2007). Our results indicate more definitely that the recently described Diplophyllaceae Potemkin (Potemkin, 1999b) is a paraphyletic assemblage. The genus Diplophyllum comprises its own clade with a highest possible support, whereas Douinia is combined with Macrodiplophyllum imbricatum and $M$. plicatum, also with a high support $(\mathrm{BS}=99 ; \mathrm{PP}=1.00)$, while $M . m i$ crodontium is placed at the base of the Scapania-clade (Figs. 1-2). Thus, it is reasonable to treat M. microdontium in Scapania as proposed by Potemkin (1999b). However, contrary to the latter publication, M. imbricatum and M. plica- 
tum are better be placed within Douinia, not Scapania, unless both species and Douinia are included in Scapania.

\section{Subclade A2}

The genera Lophozia, Lophoziopsis, Tritomaria and Heterogemma are forming this subclade. In our previous study (Vilnet at al., 2008), Lophozia s. str. (excluding L. sudetica), was resolved as a monophyletic group with a relatively high support (90\% and more). Analysis of enlarged species set shows that the Tritomaria+ Heterogemma-clade split Lophozia s.str. into two clades that have the highest possible posterior probability in BA. Based on tree topologies, we segregated the species of Lophozia s.str. with red, purplish and red-brown gemmae to a new genus Lophoziopsis Konstant. \& Vilnet (Konstantinova $\&$ Vilnet, 2009).

\section{Clade $B$}

This clade is formed by genera that were segregated from Lophoziaceae into Anastrophyllaceae by Söderström et al. (2010) that was called as «a new undescribed family». in the Checklist of liverworts of Russia (Konstantinova, Bakalin et al., 2009).

\section{Subclade B1}

This subclade composed only by two genera: Barbilophozia and recently described Pseudolophozia Konstant. \& Vilnet (Kostantinova \& Vinet, 2009). All four studied species of Barbilophozia compose a clade although without high support ( $\mathrm{PP}=0.77)$. Recently described $B$. rubescens (Schuster \& Damsholt, 1987) appears to be a hybrid between $B$. barbata and $B$. hatcheri due to inheritance of the ITS1-2 from the first species and the trnL-F from the second species (Vilnet et al., 2009b). Barbilophozia hatcheri and B. lycopodioides, the species that have been considered as closely related or even conspecific (Schljakov, 1980), are clearly separated in both $\mathrm{MP}$ and BA analyses.

Psedolophozia (Protolophozia) debiliformis and $P$. (Lophozia) sudetica form a clade (BS=100; $\mathrm{PP}=1.00)$ sister to Barbilophozia clade. Söderström et al. (2010) suggested to segregate them as Barbilophozia subgen. Sudeticae (Schljakov) L. Söderstr., De Roo et Hedd. However p-distances between $P$. debiliformis $+P$. sudetica and the genus Barbilophozia is $1.8-4.2 \%$, whereas they are only $1.2 \%$ between Barbilophozia species. Morphological differences and the level of genetic distances in comparison with other taxa from clade B, convinced us to describe a new genus Pseudolophozia Konstant. \& Vilnet (Kostantinova \& Vinet, 2009). The sequence variation within Pseudolophozia is ca. $1 \%$, that is two times higher than in Barbilophozia spp., so we hesitate to combine Pseudolophozia (Lophozia) sudetica and $P$. debiliformis in one species as it was proposed by Söderström et al. (2010).

\section{Subclade B2}

Majority of genera assigned earlier to the Lophoziaceae is located here. The genus Orthocaulis in its traditional circumscription includes ca. 10 species (Schaljakov, 1981), but as it is evident from the obtained trees, this genus is polyphyletic. The studied species previously referred to the genus occur in three clades, accepted as genera: Orthocaulis (O. floerkei+O. attenuatus $+O$. binsteadii), Schljakovianthus (S. quadrilobus) and Schljakovia (S. kunzeana) (Figs. 12). This correspondes with the quite distinct habitus of taxa. Schljakovianthus quadrilobus differs from Schljakovia and Orthocaulis s. str. in very deeply divided 4-lobed leaves with distinctly reflexed margins and sinus vs. less deeply divided 2-lobed, slightly reflexed margins in Schljakovia kunzeana and 3-lobed no reflexed margins in $O$. floerkei $+O$. attenuatus $+O$. binsteadii. Furthermore Schljakovianthus quadrilobus develops brownish or blackish brown pigmentation and has coarsely verrucose cuticle while the rest of studied taxa have yellow-brown to chestnut brown secondary pigmentation and faintly delicately $(O$. floerkei+O. attenuatus) to slightly striate-verruculose cuticle (Schljakovia kunzeana, O. binsteadii). The means of p-distances between these clades (1.2-3\%) (see supplement) together with quite distinctive morphology encourage us to separate the monospecific genera Schljakovianthus and Schljakovia from Orthocaulis (cf. Konstantinova \& Vilnet, 2009). In trees constructed by De Roo et al. (2007), the genus Orthocaulis was also divided into three clades: $O$. floerkei+O. attenuatus, $O$. atlanticus $+O$. cavifolius and $O$. quadrilobus. Later a new genus Neoorthocaulis L Söderstr., De Roo \& Hedd. was described (Söderström et al., 2010). It includes O. floerkei, O. attenuatus 
and $O$. binsteadii whereas $O$. atlanticus and $O$. cavifolius are left in Orthocaulis. There is no certainty now in the relation between Neoorthocaulis and Orthocaulis due to differences of species sampling in our and De Roo et al. (2007)' studies.

The topology of trees obtained in the present analysis supports the narrow generic concept for the genus Anastrophyllum s.l. with segregation of three genera: Anastrophyllum s.str., Sphenolobus (Lindb.) Berggr. and Crossocalyx Meyl. that was previously suggested on cpDNA loci data by Yatsentyuk et al. (2004) and De Roo et al. (2007).

Plicanthus birmensis was found within Tetralophozia (R.M. Schust.) Schljakov, although differences between nucleotide sequences of these taxa are relatively high $(1.8 \%)$ and correspond with differences between genera in clade B. Due to insufficient species sampling the taxonomical status of Plicanthus is not discussed here.

Jamesoniella, a genus with predominantly South Hemispheran distribution, has been placed, in a distinct subfamily of Jungermanniaceae by Schuster (1970) and Schljakov (1980) or in a subfamily of Lophoziaceae by Grolle \& Long (2000). Two Northern Hemisphere species, Jamesoniella undulifolia and $J$. autumnalis, were placed in the subgenus Crossogyna by Schuster (1969) and later in the genus Crossogyna by Schljakov (1981). Molecular phylogenetic studies suggested to place Jamesoniella in a separate family Jamesoniellaceae (He-Nygren et al., 2006) or in the family Adelanthaceae (Feldberg et al., 2010). The genus Jamesoniella was shown to be polyphyletic with one of the two mostly North Hemisphaeran species $J$. autumnalis separated in its own lineage (De Roo et al., 2007; Hentschel et al., 2007) or clustered with morphologically similar J. nipponica (Feldberg et al., 2010). Recently based on molecular data the most species of Jamesoniella were transferred to the genus Syzigiella Spruce (Feldberg et al., 2010). We have studied two predominantly Holarctic species of genus/subgenus Crossogyna including worldwide rare and morphologically isolated $C$. undulifolia that was never analyzed molecularly before. In obtained trees $C$. undulifolia forms a separate lineage within clade $\mathrm{B}$, whereas $C$. autumnalis is found in basal grade as a separate lineage or together with Iwatsukia Kitag. (Figs. 1-2). Based on these data as well as on morphological peculiarities of $C$. undulifolia that were discussed by Schuster (1969) and Schljakov (1981), this species is segregated in monotypic genus, Biantheridion (Grolle) Konstantinova \& Vilnet (Konstantinova \& Vilnet, 2009).

The systematic position of oligotypic genus Isopaches $\mathrm{H}$. Buch is questionable. Both MP and BA analyses put it at a base of $(\mathrm{A}+\mathrm{B})$ clade $(\mathrm{BS}=100, \mathrm{PP}=1.00)$ (Figs. 1-2). De Roo et al. (2007) found it within "Anastrophyllaceae"-clade only in BA tree, whereas in MP tree it is located in "Scapaniaceae"-clade. Söderström et al. (2010) placed Isopaches in Anastrophyllaceae. Additional study is needed to resolve the problem with this genus.

The treatment of Obtusifolium obtusum and Protolophozia elongata as a members of Scapaniaceae (Söderström et al., 2010) is not confirmed due to unstable position of these taxa in obtained trees.

\section{Clade C}

Clade $\mathrm{C}$ is composed by members of the families Gymnomitriaceae, Jungermanniaceae s.str. and recently described Solenostomataceae (Crandall-Stotler et al., 2009). The terminal position in this clade is occupied by the family Gymnomitriaceae. Earlier, with more limited taxa sampling, this family was recognized as monophyletic (Yatsentyuk et al., 2004; Schill et al., 2004). However, the genus Eremonotus classified for a long time in the Gymnomitriaceae (Schuster, 1984; Grolle, 1983; etc.), was found here within the clade formed by Jungermannia s. str., Mesoptychia, Leiocolea and Liochlaena (Figs. 12 ), which generally agrees with the results of Henstchel et al. (2007) and with the placement of Eremonotus in Jungermanniaceae by CrandallStotler et al. (2009).

The genera Gymnomitrion and Marsupella are found to be polyphyletic, with the species intermingled and distributed into two main clades (Figs. 1-2) that have some morphological definition. The main Marsupella clade is formed by species with well-developed perianth and perigynium, including Marsupella apiculata (previously treated as Gymnomitrion apiculatum) that has perianth and perigynium similar to that in most Marsupella species. Contrary to that, three spe- 
cies with more or less reduced perianth and perigynium, Gymnomitrion alpinum, G. brevissimum and $G$. commutatum, which usually are placed in Marsupella, are located in the Gymnomitrion clade. Based on these results the rearrangement of Gymnomitriaceae species was made in Checklist of liverworts of Russia (Konstantinova, Bakalin et al., 2009) and later accepted in the study of Gymnomitriaceae by Ván̆a et al. (2010).

Three morphologically allied species, Marsupella arctica, M. aquatica and M. emarginata, are combined in a clade. Marsupella aquati$c a$ has been classified as a variety of M. emarginata by some authors (e.g. Schuster, 1974; Grolle $\&$ Long, 2000). The trnL-intron of M. emarginata is characterized by unique 43 base pairs deletion compared to both $M$. aquatica and $M$. arctica (Vilnet et al., 2007b). The value of p-distances between $M$. arctica and M. emarginata is higher than between $M$. aquatica and $M$. emarginata (2.4 and $1.2 \%$ correspondingly). Nevertheless, it would be more reasonable to recognize these taxa at one rank taking into account morphological features listed by Schuster (1972), Schljakov (1981) etc., and to accept Marsupella aquatica as a distinct species.

The monotypic genus Prasanthus Lindb. is characterized by presence of fleshy perigynium and lacking of perianth. It forms a basal lineage in a clade composed by Gymnomitriaceae species with developed perianth and perigynium in both trees (Figs. 1-2).

The studied species of Nardia compose a clade sister to Gymnomitriaceae with 0.99 support in BA tree (Fig. 2) and a low support $(\mathrm{BS}=67 \%$ ) in MP tree (Fig. 1). Crandall-Stotler et al. (2009) placed Nardia in the recently described family Solenostomataceae. However our data show that the inclusion of Nardia makes Solenostomataceae paraphyletic and suggest either to place Nardia in Gymnomitriaceae or segregate it to its own family.

In the trees obtained here and those of Hentschel et al. (2007), Solenostoma and Plectocolea compose an intermingled clade. Majority of authors included Plectocolea in Solenostoma following modern molecular data (Crandall-Stotler et al., 2009; Váňa \& Long, 2009). However, species sampling seems to be not enough for the final decision on taxonomic position of Solenostoma and Plectocolea.
Genera Jungermannia s.str., Eremonotus, Mesoptychia, Leiocolea and Liochalena form a subclade within clade C. In general it corresponds to Jungermanniaceae sensu Hentschel et al. (2007), although differs from the family circumscription of Crandall-Stotler et al. (2009) that placed Liochalena and Delavayella in a separate oligotypic family Delavayellaceae.

\section{CONCLUSIONS}

Our molecular data support segregation of the family Anastrophyllaceae, but the position of the genus Isopaches remains uncertain, as well as the position of Obtusifolium and Protolophozia elongata in the family Scapaniaceae.

The position of the genus Nardia within Solenostomataceae is not supported; this genus is better be placed in Gymnomitriaceae or to its own family.

The genera Lophozia s.str., Schistochilopsis, Tritomaria, Protolophozia, Orthocaulis and Crossogyna in their traditional circumscription are found to be polyphyletic. The segregation of genera Pseudotritomaria, Heterogemma, Lophoziopsis, Pseudolophozia, Schljakovianthus, Schljakovia and Biantheridion are suggested by molecular data.

Species of Marsupella with more or less reduced perianth and perigynium should be referred to Gymnomitrion, whereas G. apiculatum that has distinct perianth and perigynium is transferred to Marsupella.

The subdivision of the genus Scapania based on morphological data is partially supported.

The segregation of Scapaniella as a genus is not supported. Macrodiplophyllum imbricatum and $M$. plicatum could be placed in the genus Douinia, unless all of these taxa be included in Scapania.

The status of Scapania tundrae, S. paludosa, S. crassiretis and Marsupella aquatica as a separate species is supported.

\section{ACKNOWLEDGMENTS}

We thank Dr. Michael S. Ignatov for helpful suggestions and discussion, Dr. Diana Horton for comments and improving the English of the first version of manuscript and Dr. Lars Söderström for careful reading and useful comments. This research has been supported by Russian Foundation for Basic Researches grants (09-04-00281, 
09-04-01324, 10-04-00050) and program for Basic Research of Russian Academy of Science "Biodiversity and dynamics of gene pools" (subprogram "Gene pools and genetic diversity").

\section{LITERATURE CITED}

ARNELL, S. 1956. Illustrated moss flora of Fennoscandia. I. Hepatacae. - Gleerup, Lund. 314.

BUCH, H. 1928. Die Scapanien Nordeuropas und Sibiriens 2. Systematischer teil. - Soc. Sci. Fenn., Comm. Biol. 3: 1-177.

BUCH, H. 1933. Vorarbeiten zu eineer Lebermoosflora FennoScandien. I. Ein Versuch zur Aufteilung der Gattungen Lophozia Dum. und Sphenolobus Step. - Memoranda Soc. Fauna Fl. Fenn. 8: 282-297.

CRANDALL-STOTLER, B., R.E. STOTLER \& D.G. LONG 2009. Phylogeny and classification of the Marchantiophyta. - Edinburgh J. Bot. 66: 155-198.

DAMSHOLT, K. 2002. Illustrated flora of Nordic liverworts and hornworts. - Nord. Bryol. Soc., Lund. 840.

DAVIS, E.C. 2004. A molecular phylogeny of leafy liverworts (Jungermanniidae: Marchantiophyta). - In: (Goffinet B., V. Hollowell \& R. Magill eds.) Molecular Systematics of Bryophytes. Monogr. Syst. Bot. St. Louis, Missouri Bot. Gard. Press, 98: 61-86.

DE ROO, R.T., T.A. HEDDERSON \& L. SÖDERSTRÖM 2007. Molecular insights into the phylogeny of the leafy liverwort family Lophoziaceae Cavers. - Taxon 56: 310-314.

FELDBERG, K., J. VÁŇA, D. LONG, A.J. SHAW, J. HENTSCHEL \& J. HEINRICHS 2010. A phylogeny of Adelanthaceae (Jungermanniales, Marchantiophyta) based on nuclear and chloroplast DNA markers, with comments on classification, cryptic speciation and biogeography. $-\mathrm{Mol}$. Phylogenet. Evol. 55: 293-304.

FORREST, L.L., E.C. DAVIS, D.G. LONG, B.J. CRANDALLSTOTLER, A. CLARK \& M.L. HOLLINGSWORTH 2006. Unraveling the evolutionary history of the liverworts (Marchantiophyta): multiple taxa, genomes and analyses. - Bryologist 109: 303-334.

GOLOBOFF, P., S. FARRIS \& K.NIXON 2003. TNT (Tree analysis using New Technology) (BETA) ver. 1.0. - Program and documentation, available from the authors, and at www.cladistics.com/aboutTNT.html.

GROLLE, R. 1983. Nomina generica Hepaticarum: references, types and synonymies. - Acta Bot. Fenn. 121: 1-62.

GROLLE, R. \& D.G. LONG 2000. An annotated check-list of the Hepaticae and Anthocerotae of Europe and Macaronesia. - J. Bryol. 22: 103-141.

HALL, T. A. 1999. BioEdit: a user-friendly biological sequence aligment editor and analysis program for Windows 95/98/ NT. - Nucl. Acids. Symp. 41: 95-98.

HEINRICHS, J., S.R. GRADSTEIN, R.WILSON \& H. SCHNEIDER 2005. Towards a natural classification of liverworts (Marchantiophyta) based on the chloroplast gene rbcL. - Cryptog. Bryol. 26: 131-150.

HENTSCHEL, J., J.A. PATON, H. SCHNEIDER \& J. HEINRICHS 2007. Acceptance of Liochlaena Nees and Solenostoma Mitt., the systematic position of Eremonotus Pearson and notes on Jungermannia L. s.l. (Jungermanniidae) based on chloroplast DNA sequence data. - Pl. Syst. Evol. 268: 147157.

HE-NYGREN, X., A. JUSLEN, D. GLENNY \& S. PIIPPO 2006. Illuminating the evolutionary history of liverworts (Marchantiophyta) - towards a natural classification. - Cladistics 22: 1-31.

KEANE, T.M., T.J. NAUGHTON \& J.O. MCINERNEY 2004. ModelGenerator: amino acid and nucleotide substitution model selection. - National University of Ireland, Maynooth. http://bioinf.may.ie/software/modelgenerator/

KITAGAWA, N. 1965. A revision of the family Lophoziaceae of Japan and its adjacent region. I. - J. Hattori Bot. Lab. 28: 239-293.

KITAGAWA, N. 1966. A revision of the family Lophoziaceae of Japan and its adjacent region. II. - J. Hattori Bot. Lab. 29: 101-149.

KONSTANTINOVA N.A., V.A. BAKALIN ET AL. 2009. Checklist of liverworts (Marchantiophyta) of Russia. - Arctoa 18: 1-64.

KONSTANTINOVA, N.A. \& A.A. VILNET 2009. New taxa and new combinations in Jungermanniales (Hepaticae). - Arctoa 18: 65-67.

KUMAR, S., K. TAMURA \& M. NEI 2004 MEGA3: Integrated software for Molecular Evolutionary Genetics Analysis and sequence alignment. - Briefings in Bioinformatics 5: 150-163.

MÜLLER, K. 2005. SeqState. Primer design and sequence statistic for phylogenetic DNA datasets. - Appl. Bioinformatics 4: $65-69$.

POTEMKIN, A.D. 1994. Studies on Scapania, Hepaticae sectio Rufidulae and sectio Nemorosae. -J. Hattori Bot. Lab. 77: 273-285.

POTEMKIN, A.D. 1999a. An analysis of the practical taxonomy of some critical northern species of Scapania (Scapaniceae, Hepaticae). - Bryologist 102: 32-38.

POTEMKIN, A.D. 1999b. Circumscription of the family Scapaniaceae, with segregation of the new family Dipophyllaceae (Hepaticae). -Ann. Bot. Fennici 36: 271-283.

POTEMKIN, A.D. 2002. Phylogenetic system and classification of the family Scapaniaceae Mig. emend. Potemkin (Hepaticae). - Ann. Bot. Fennici 39: 309-334.

RONQUIST, F., \& J.P. HUELSENBECK 2003. MRBAYES 3: Bayesian phylogenetic inference under mixed models. - Bioinformatics 19: 1572-1574.

SCHILL, D.B., D.G. LONG, M. MOELLER \& J. SQUIRRELL 2004. Phylogenetic relationships between Lophoziaceae and Scapaniaceae based on chloroplast sequences. - In: (Goffinet B., V. Hollowell \& R. Magill eds.) Molecular Systematics of Bryophytes. Monogr. Syst. Bot. St. Louis, Missouri Bot. Gard. Press: 98: 141-149.

[SCHLJAKOV, R.N.] ШЛЯКОВ P.Н. 1980. Печеночные мхи Севера CCCP. - [The Hepatics of the North of the USSR] Л., Наука [Leningrad, Nauka] 3: 1-188.

[SCHLJAKOV, R.N.] ШЛЯКОВ Р.Н. 1981. Печеночные мхи Севера CCCP. - [The Hepatics of the North of the USSR] Л., Наука [Leningrad, Nauka] 4: 1-221. 
SCHUMACKER, R. \& J. VÁŇA 2005. Identification keys to the liverworts and hornworts of Europe end Macaronesia (distribution and status). - Poznan, Sorus: 1-212.

SCHUSTER, R.M. 1966. The Hepaticae and Anthocerotae of North America east of the hundredth meridian, Vol. 1. - New York, Columbia University Press: 1-802.

SCHUSTER, R.M. 1969. The Hepaticae and Anthocerotae of North America east of the hundredth meridian, Vol. 2. - New York, Columbia University Press: 1-1062.

SCHUSTER, R.M., 1970. Studies on Hepaticae. XVIII. The family Jungermanniaceae, s. lat.: a reclassification. - Trans. British Bryol. Soc. 6: 86-107.

SCHUSTER, R.M., 1974. The Hepaticae and Anthocerotae of North America east of the hundredth meridian, Vol. 3. - New York, Columbia University Press: 1-880.

SCHUSTER, R.M. 1984. Evolution, phylogeny and classification of the Hepaticae. - In: (Schuster, R.M. eds.) New manual of Bryology. J. Hattori Bot. Lab. Vol. 2: 892-1071.

SCHUSTER, R.M. \& K. DAMSHOLT 1987. Some new taxa of Jungermanniales. - Phytologia 63: 325-328.

SÖDERSTRÖM, L., R. DE ROO \& T. HEDDERSON 2010. Taxonomic novelties resulting from recent reclassification of the Lophoziaceae/Scapaniaceae clade. - Phytotaxa 3: 4753.

TABERLET, P., L. GIELLY, G. PAUTOU \& J. BOUVET 1991. Universal primers for amplification of three non-coding regions of chloroplast DNA. - Plant Mol. Biol. 17: 1105-1109.

VÁŇA, J. \& D.G. LONG 2009. Jungermanniaceae of the SinoHimalayan region. - Nova Hedwigia 89: 485-517.

VÁŇA, J., L. SÖDERSTRÖM, A. HAGBORG, M. KONRAT J. 2010. Early land plants today: taxonomy, systematics and nomenclature of Gymnomitriaceae. - Phytotaxa 11: 1-80.

VILNET, A.A., N.A. KONSTANTINOVA \& A.V. TROITSKY 2006. The molecular divergence between some closely allied taxa of genus Scapania (Dumort.) Dumort. - Sustainable of ecosystems and problems of preservation of bio- logical diversity in the North. Proceedings of the International conference, Kirovsk: 49-53.

VILNET, A.A., N.A. KONSTANTINOVA \& A.V. TROITSKY 2007b. On molecular phylogeny of Gymnomitriaceae $H$. Klinggr. (Hepaticae). - Computational Phylogenetics and molecular systematics. Conference proceedings, Moscow: 27-29.

VILNET, A.A., N.A. KONSTANTINOVA \& A.V. TROITSKY 2008. Phylogeny and systematics of the genus Lophozia s. str. (Dumort.) Dumort. (Hepaticae) and related taxa from nuclear ITS1-2 and chloroplast trnL-F sequences. - Mol. Phylogenet. Evol. 47: 403-418.

VILNET, A.A., N.A. KONSTANTINOVA \& A.V. TROITSKY 2009a. Genosystematics and new insight into the phylogeny and taxonomy of liverworts. - Molecular biology 43: 845855.

VILNET, A.A., N.A. KONSTANTINOVA \& A.V. TROITSKY 2009b. Systematics of Barbilophozia Loeske (Marchantiophyta): evidence from DNA sequences data. - Programme and Abstracts of $17^{\text {th }}$ Symposium "Cryptogamic botany», Tomar: 77-78.

VILNET, A.A., I.A. MILYUTINA, N.A. KONSTANTINOVA, M.S. IGANTOV \& A.V. TROITSKY 2007a. Phylogeny of the genus Lophozia (Dumort,) Dumort. inferred from nuclear and chloroplast sequences ITS1-2 and trnL-F. - Russian J. Genetics 43: 1306-1313.

WHITE, T.J., T. BRUNS, S. LEE \& J. TAYLOR 1990. Amplification and direct sequencing of fungal ribosomal RNA genes for phylogenetics. - In: (Innis M.A., D.H. Gelfand, J.J. Snisky \& T.J. White eds.) PCR protocols: a guide to methods and applications. San Diego, CA: 315-322.

YATSENTYUK, S.P., N.A. KONSTANTINOVA, M.S. IGNATOV, J. HYVÖNEN \& A.V. TROITSKY 2004. On phylogeny of Lophoziaceae and related families (Hepaticae, Jungermanniales) based on trnL-trnF intron-spacer sequences of chloroplast DNA. - In: (Goffinet B., V. Hollowell \& R. Magill eds.) Molecular Systematics of Bryophytes. Monogr. Syst. Bot. St. Louis, Missouri Bot. Gard. Press: 98: 150-167.

Table 1. The list of taxa, specimens vouchers and GenBank accession numbers

Taxon

Anastrepta orcadensis (Hook.) Schiffn. Anastrophyllum assimile (Mitt.) Steph.

A. michauxii (F. Weber) H.Buch

A. sphenoloboides R.M. Schust. 1

A. sphenoloboides R.M. Schust. 2

Barbilophozia barbata (Schmidel ex Schreb.) Loeske 1

B. barbata (Schmidel ex Schreb.) Loeske 2

B. hatcheri (A. Evans) Loeske 1

B. hatcheri (A. Evans) Loeske 2

B. lycopodioides (Wallr.) Loeske 1

B .lycopodioides (Wallr.) Loeske 2

B. rubescens (R.M. Schust. \& Damsh.)

Kartt.et L. Söderstr. 1
Herbarium voucher

Russia, Buryatia, Konstantinova, 59-1-01 (KPABG)

USA, Konstantinova, A 137-18-95 (KPABG)

Russia, Buryatia, Konstantinova, 17-1-02 (KPABG)

Norway, Spitsbergen, Konstantinova, K 50-3-06 (KPABG)

Russia, Murmansk Prov., Bakalin, 23-03-01 (KPABG)

Netherlands, Konstantinova, 3b-5-99 (KPABG)

Russia, Kamchatka Prov., Bakalin, 56-8-01-VB (KPABG)

Russia, Kamchatka Prov., Bakalin, K 7-3-03 (KPABG)

Norway, Spitsbergen, Konstantinova, K 60-4-06 (KPABG)

Russia, Kuril Is., Paramushir, Bakalin, K 100-13-04 (KPABG)

Russia, Murmansk Prov., Konstantinova,16-4-00 (KPABG)

Russia, Murmansk Prov., Konstantinova, 409-92 (KPABG)
Accession no.

trnL ITS

DQ875088 DQ875126

EU791664 EU791776

DQ875087 DQ875125

EU791662 EU791777

EU791663 EU791778

EU791676 EU791779

EU791677 EU791780

EU791675 EU791782

EU791674 EU791781

EU791673 EU791783

EF090627 EF090632

EF090628 EF090633 
Taxon

B. rubescens (R.M. Schust. et Damsh.)

Kartt.et L. Soderstr. 2

Biantheridion undulifolium (Nees)

Konstant. \&Vilnet 1

B. undulifolium (Nees) Konstant. \&Vilnet) 2

Crossocalyx hellerianus (Nees) Meyl.

Diplophyllum albicans (L.) Dumort. 1

D. albicans (L.) Dumort. 2

D. obtusifolium (Hook.) Dumort.

D. taxifolium (Wahlenb.) Dumort.

Douinia ovata (Dicks.) H. Buch

D. ovata (Dicks.) H. Buch

Eremonotus myriocarpus (Carrington) Pearson

Gymnocolea inflata (Huds.) Dumort. 1

G. inflata (Huds.) Dumort. 2

Gymnomitrion alpinum (Gottsche ex

Husn.) Schiffn. 1

G. alpinum Gottsche ex Husn.) Schiffn. 2

G. brevissimum (Schleich. ex

Dumort.) Warnst. 1

G. brevissimum (Schleich. ex

Dumort.) Warnst. 2

G. commutatum (Limpr.) Schiffn.

G. concinatum (Lightf.) Corda 1

G. concinatum (Lightf.) Corda 2

G. concinatum (Lightf.) Corda 3

G. corallioides Nees

G. pacificum Grolle

Herbertus dicranus (Tayl.) Trev.

Heterogemma capitata (Hook.)

Konstant. \&Vilnet

H. laxa (Jørg.) Konstant. \&Vilnet)

Isopaches bicrenatus (Hoffm.) H. Buch

I. decolorans (Limpr.) H. Buch

Iwatsukia jishibae (Steph.) Kitag.

Jamesoniella autumnalis (DC.) Steph. 1

J. autumnalis (DC.) Steph. 2

Jungermannia atrovirens Dumort. 1

\section{J. atrovirens Dumort. 2}

J. atrovirens Dumort. 3

J. atrovirens Dumort. 4

Leiocolea badensis (Gottsche) Jörg. 1

L. badensis (Gottsche) Jörg. 2

Liochlaena lanceolata Nees

Lophozia ascendens (Warnst.) R. M. Schust.

L. austro-sibirica Bakalin

L. heteromorpha R. M. Schust.

L. cf. lacerata N. Kitag.

L. lantratoviae Bakalin
Herbarium voucher

Russia, Magadan Prov., Mochalova \& Bakalin, G106852 (KPABG)

Accession no.

$\operatorname{trn} \mathrm{L}$

ITS

EU791678 EU791784

Russia, Kemerovo Prov., Konstantinova, 56-1-00(KPABG) EU791671 EU791794

Russia, Buryatia, Konstantinova, 85-1-02 (KPABG)

Russia, Karelia Rep., Bakalin, 6.VIII.1997 (KPABG)

Russia, Caucasus, Karachayevo-Cherkessian Rep.,

Konstantinova, K446-7-05 (KPABG)

Norway, Spitsbergen, Konstantinova, K 121-6-06(KPABG)

Russia, Amur Prov., Bakalin, 14.VII.2000 (KPABG)

Russia, Karelia, Bakalin, 28.VII.1998 (KPABG)

USA, Washington, A. Potemkin, 95/401 (KPABG)

USA, Washington, Konstantinova, A116-95 (KPABG)

Russia, Caucasus, Karachayevo-Cherkessian Rep.,

Konstantinova, K446-6-05 (KPABG)

Norway, Spitsbergen, Konstantinova 118-1-04 (KPABG)

Russia, Nizhny Novgorod Prov..

Konstantinova, 129-2a-03 (KPABG)

EU791672 EU791795

AY327780 EU791788

EU791659 EU791773

EU791660 EU791774

AY327782 EU791775

AY327762 EU791772

AY327778 -

- $\quad$ EU791771

EU791716 EU791839

EU791661 EU791787

GQ220785 GQ220783

Russia, Buryatia, Konstantinova, 83-2-02 (KPABG)

Russia, Sakhalin Prov., Bakalin, 58-30-05 (KPABG)

EU791707 EU791828

EU791706 EU791827

Russia, Murmansk Prov. Konstantinova, G8171 (KPABG)

EU791711 EU791833

Russia, Kamchatka Prov., Bakalin, HRE

Russia, Khabarovskiy Kray, Ignatov, 97-1025 (KPABG)

Russia, Murmansk Prov., Konstantinova, 366-00 (KPABG)

Russia, Caucasus, Karachayevo-Cherkessian Rep.,

Konstantinova, K465a-05 (KPABG)

EU791712 EU791834

EU791708 EU791829

AF519202 EU791832

EU791710 EU791831

Russia, Caucasus, Karachayevo-Cherkessian Rep.,

Konstantinova, K493-05 (KPABG)

Norway, Spitsbergen, Konstantinova, 155-04 (KPABG)

Russia, Commander Is., Bakalin, K-26-4-02-VB (KPABG)

Russia, Primorskiy Kray, Bakalin, P-74-15-05 (KPABG)

Russia, Nizhny Novgorod

Prov., Konstantinova, 132-03 (KPABG)

Russia, Murmansk Prov., Konstantinova, 40-6-94 (KPABG)

Russia, Yakutia, Bakalin, 18.VII.2000 (KPABG)

Russia, Caucasus, Karachayevo-Cherkessian Rep.,

Konstantinova, K464-3-05 (KPABG)

Russia, Buryatia, Konstantinova 48-1-01 (KPABG)

Russia, Maryi-El Rep., Konstantinova, K 448-5-04(KPABG) EU791720 EU791844

Russia, Buryatia, Konstantinova, 103-1-01 (KPABG)

Russia, Caucasus, Karachayevo-Cherkessian Rep.,

Ignatov \& Ignatova, 4.VIII.2002 (KPABG)

Russia, Caucasus, Karachayevo-Cherkessian Rep.,

Konstantinova, K 421- 6-05 (KPABG)

Russia, Kamchatka Prov., Bakalin K-74-13a-04 (KPABG)

Russia, Buryatia, Konstantinova, 21-4-02 (KPABG)

Russia, Amur Prov., Bakalin, 33-1-00 VB (KPABG)

EU791709 EU791830

EU791705 EU791826

EU791713 EU791835

EU791724 EU791849

DQ875080 DQ875119

DQ875084 DQ875053

AY327788 EU791797

EU791680 EU791798

EU791680 EU791798

EU791721 EU791845

GQ220766 GQ220782

GQ220763 GQ220779

GQ220764 GQ220780

GQ220765 GQ220781

EU791718 EU791842

Russia, Komi Rep., Dulin, Konstantinova, 101313 (KPABG) EU791717 EU791841

Russia, Murmansk Prov., Konstantinova, 206-2-02 (KPABG) EU791719 EU791843

Russia, Buryatia, Konstantinova, 109-3-01 (KPABG) DQ875054 DQ875089

Russia, Buryatia, Bakalin, B 15-9-99 (KPABG) DQ875069 DQ875105

Russia, Kamchatka Prov., Bakalin, K-47-3-02 (KPABG) DQ875068 DQ875104

Russia, Commander Island, Bakalin, K-3-2-02-VB (KPABG) DQ875071 DQ875107

Russia, Buryatia, Bakalin, 76-7-01 (KPABG) 
Taxon

L. schusteriana Schljakov

L. silvicola $\mathrm{H}$. Buch

L. silvicola $\mathrm{H}$. Buch

L. silvicoloides N. Kitag. 1

L. silvicoloides N. Kitag. 2

L. silvicoloides N. Kitag. 3

L. silvicoloides $\mathrm{N}$. Kitag. 3

L. cf. wenzelii (Nees) Steph. var. groenlandica (Nees) Bakalin

L. ventricosa (Dicks.) Dumort. var. guttulata (Lindb. et S.W. Arnell) Bakalin

L. ventricosa (Dicks.) Dumort. var. longiflora (Nees) Macoun

L. wenzelii (Nees) Steph. var. groenlandica (Nees) Bakalin

L. wenzelii (Nees) Steph. var. lapponica $\mathrm{H}$. Buch et S.W. Arnell

L. wenzelii (Nees) Steph. var. litoralis ( S.W. Arnell) Bakalin

L. wenzelii (Nees) Steph. var. massularioides Bakalin

Lophoziopsis excisa (Dicks.)

Konstant. \&Vilnet 1

L. excisa (Dicks.) Konstant. \&Vilnet 2

L. longidens (Lindb.) Konstant. \&Vilnet

L. pellucida (R. M. Schust.)

Konstant. \&Vilnet 1

L. pellucida (R. M. Schust.)

Konstant. \&Vilnet 2

L. polaris (R. M. Schust.)

Konstant. \&Vilnet) 1

L. polaris (R. M. Schust.)

Konstant. \&Vilnet) 1

L. polaris (R. M. Schust.)

Konstant. \&Vilnet 2

L. propagulifera (Gottsche)

Konstant. \&Vilnet)

Macrodiplophyllum imbricatum M. Howe

M. microdontium (Mitt.) Perss.

M. plicatum (Lindb.) Perss.

Marsupella apiculata Schiffn. 1

M. apiculata Schiffn. 2

M. aquatica (Lindenb.) Schiffn. 1

M. aquatica (Lindenb.) Schiffn. 2

M. arctica (Berggr.) Bryhn et Kaal.

M. boeckii (Austin) Kaal. 1

M. boeckii (Austin) Kaal. 2

M. distichii Steph.

M. emarginata (Ehrh.) Dumort. 1

M. emarginata (Ehrh.) Dumort. 2

M. emarginata (Ehrh.) Dumort. 3

M. funckii (F. Web. et D. Mohr) Dumort.
Herbarium voucher

Russia, Murmansk Prov., Bakalin, G9331 (KPABG)

Russia, Karelia, Bakalin, 02.VIII.1998 (KPABG)

Russia, Nizhny Novgorod Prov.,

Konstantinova, 124-1-03 (KPABG)

Accession no.

trnL ITS

DQ875067 DQ875103

AF519197 -

Russia, Murmansk Prov. Konstantinova, 356-4-00(KPABG) DQ875064 DQ87509

Russia, Kamchatka Prov., Bakalin, K -57-23-02-VB (KPABG) DQ875063 DQ875098

Norway, Spitsbergen, Konstantinova, 150-6-04 (KPABG) DQ875065 -

Norway, Spitsbergen, Konstantinova, 150-2-04(KPABG) — _ DQ875100

Russia, Kemerovo Prov., Konstantinova, 67-3-00 (KPABG) DQ875070 DQ875106

Russia, Buryatia, Konstantinova, 81-1-01 (KPABG)

DQ875072 DQ875108

Russia, Chita Prov., Bakalin, 11-5-00 (KPABG)

DQ875066 DQ875101

Russia, Murmansk Prov., Konstantinova, 9329 (KPABG)

DQ875073 DQ875109

Norway, Spitsbergen, Konstantinova,124-2-04 (KPABG)

DQ875076 DQ875112

Russia, Murmansk Prov., Bakalin,12-3-02 (KPABG)

DQ875074 DQ875110

Russia, Caucasus, V. Onipchenko, 31.VIII.83 (MHA)

DQ875075 DQ875111

Russia, Murmansk Prov., Konstantinova, 41-2-97 (KPABG)

Norway, Spitsbergen, Konstantinova, K-21-2-05 (KPABG)

Russia, Murmansk Prov., Konstantinova, 360-2-00(KPABG)

Russia, Komi Rep., M. Dulin, 103640 (KPABG)

EF065686 EF065694

Russia, Murmansk Prov., Konstantinova, 39-2a-03(KPABG) EF065687 EF065695

Russia, Kamchatka Prov., Bakalin, 30-01-02 (KPABG) ～DQ875060 —

Norway, Spitsbergen, Konstantinova, K-9-2-05(KPABG) — - DQ875095

Russia, Yakutia, Bakalin, 23-11-00 (KPABG)

DQ875061 DQ875096

Russia, Kamchatka Prov., Bakalin, K-53-6-02-VB (KPABG) DQ875062 DQ875097 USA, Alaska, Konstantinova, 110-2-92a(KPABG)

EU791658 EU791770

Russia, Buryatia, Konstantinova, 146/12-01 (KPABG)

Russia, Kamchatka Prov., Bakalin, 22.VIII.2001

Norway, Spitsbergen, Konstantinova, K93-1-06 (KPABG)

Russia, Chita Prov., Bakalin, 5-13-00 (KPABG)

AF519199 EU791769

AF519198 EU791768

EU791699 EU791819

EU791698 EU791818

Russia, Murmansk Prov., Konstantinova, 152/5-87 (KPABG) AF519201 EU791813

Russia, Caucasus, Karachayevo-Cherkessian Rep.,

Konstantinova, K 517-4-05 (KPABG)

Norway, Spitsbergen, Konstantinova, 128-04 (KPABG)

Russia, Murmansk Prov., Konstantinova, 367-2-00(KPABG)

Norway, Spitsbergen, Konstantinova, K93-2a-06 (KPABG)

Japan, Deguchi \& Yamaguchi,

Bryophytes of Asia \#170 (2000) (KPABG)

Russia, Murmansk Prov., Konstantinova, 354-4-00 (KPABG)

Russia, Buryatia, Konstantinova, 44-01 (KPABG)

Russia, Buryatia, Konstantinova, 23-4-02 (KPABG)

EU791694 EU791814

EU791695 EU791815

EU791696 EU791816

EU791697 EU791817

EU791703 EU791824

EU791693 EU791812

EU791691 EU791810

EU791692 EU791811

Russia, Caucasus, Karachayevo-Cherkessian Rep.,

Konstantinova, K 516-1-05 (KPABG) 
Taxon

M. sphacelata (Gieseke ex Lindenb.) Dumort. 1 M. sphacelata (Gieseke ex Lindenb.) Dumort. 2 M. sprucei (Limpr.) Bernet

Mesoptychia sahlbergii (Lindb.) A. Evans

Mylia taylorii (Hook.) Gray

Mylia verrucosa Lindb.

Nardia assamica (Mitt.) Amak.

Nardia compressa (Hook.) Gray

Nardia insecta Lindb.

Obtusifolium obtusum (Lindb.) S.W. Arnell Obtusifolium obtusum (Lindb.) S.W. Arnell Orthocaulis attenuatus (Mart.) A. Evans 1 O. attenuatus (Mart.) A. Evans 2

O. binsteadii (Kaal.) H. Buch 1

O. binsteadii (Kaal.) H. Buch 2

O. floerkei (E. Weber \& D. Mohr) H. Buch 1

O. floerkei (E. Weber \& D. Mohr) H. Buch 2 Plectocolea obovata (Nees) Mitt. 1

P. obovata (Nees) Mitt. 2

P. obovata (Nees) Mitt. 3

P. subelliptica (Lindb. Ex Kaal.) A. Evans

P. sp. 1

P. sp. 2

P. sp. 3

Plicanthus birmensis (Steph.) R.M. Schust.

Prasanthus suecicus (Gottsche) Lindb.

Protolophozia elongata (Steph.) Schljakov

Pseudolophozia debiliformis (R.M. Schust. \& Damsh.) Konstant. \&Vilnet 1

P. debiliformis (R.M. Schust. \& Damsh.) Konstant. \&Vilnet) 2

P. debiliformis (R.M. Schust. \& Damsh.) Konstant. \&Vilnet) 3

Pseudolophozia sudetica (Nees ex

Huebener) Konstant. \&Vilnet) 1

P. sudetica (Nees ex Huebener)

Konstant. \&Vilnet 2

P. sudetica (Nees ex Huebener)

Konstant. \&Vilnet) 3

P. sudetica (Nees ex Huebener)

Konstant. \&Vilnet) 4

Pseudotritomaria heterophylla

(R.M. Schust.) Konstant. \&Vilnet 1

P. heterophylla (R.M. Schust.)

Konstant. \&Vilnet 2

Saccobasis polita (Nees) H. Buch

S. polymorpha (R.M. Schust.) Schljakov 1

S. polymorpha (R.M. Schust.) Schljakov 2

Scapania americana Müll. Frib.

S. apiculata Spruce

S. aspera Bernet et M. Bernet

S. bolanderi Austin

S. calcicola (H. Arnell et J. Perss) Ingham

S. crassiretis Bryhn.

S. curta (Mart.) Dumort.

S. cuspiduligera (Nees) Müll.Frib.
Herbarium voucher

Accession no.

$\operatorname{trn} \mathrm{L} \quad \mathrm{ITS}$

Russia, Kemerovo Prov., Konstantinova, 65/1-00(KPABG) AF519200 EU791821 Russia, Murmansk Prov., Konstantinova, 58-5-97(KPABG) EU791701 EU791822 Russia, Kemerovo Prov., Konstantinova, 54-1-00 (KPABG) HQ833031 EU791823 Russia, Chukotka, Afonina, 10.VIII.1979(KPABG)

Russia, Buryatia, S. Kazanovsky, 26.VII.1990(LE) AF519189 EU791840 AY327779 EU791847 Russia, Primorskiy Kray, Bakalin, P-73-9-05(KPABG) ～EU791723 EU791848 Russia, Kuril Islands, Iturup, Bakalin, K 54-1a-05 (KPABG) EU791715 EU791838 Canada, Konstantinova, A97/1-95 (KPABG) Belgium, Konstantinova, 102077 (KPABG) Russia, Murmansk Prov., Bakalin, 1.VII.2001 (KPABG) AF519188 EU791837 EU791714 EU791836 AY327769 -

Russia, Permskiy Kray, Konstantinova, K-315-1-04(KPABG)-_ DQ875118 Russia, Sakhalin Prov., Harpel, Cherdantseva, 105728(KPABG) EU722343 EU727538 Russia, Murmansk Prov., Konstantinova, 29-3-97(KPABG) EU722344 EU727539 Russia, Amur Prov., Bakalin, 34-3-00VB (KPABG)

Russia, Murmansk Prov., Bakalin, 8-3-02 (KPABG) EU722345 EU727540 EU722346 EU727541 Russia, Murmansk Prov., Konstantinova, 191-1-02(KPABG) EU722348 EU727543 Russia, Permskiy Kray, Konstantinova, K 322-4-04 (KPABG) EU722347 EU727542 Russia, Murmansk Prov., Konstantinova, 196-6-02 (KPABG) GQ220754 GQ220770 Russia, Kemerovo Prov., Konstantinova, 72-2-00(KPABG) GQ220753 GQ220769 Russia, Permskiy Kray, Konstantinova, K 324-1-04 (KPABG) GQ220755 GQ220771 Russia, Kamchatka Prov., Bakalin, K-48-13-03 (KPABG) ～GQ220752 GQ220768 Russia, Murmanka Prov., Konstantinova, 30-1-97 (KPABG) GQ220761 GQ220777 Russia, Caucasus, Karachayevo-Cherkessian Rep.,

Konstantinova K 495-2-05 (KPABG)

Russia, Buryatia, Konstantinova, 70-2-01 (KPABG)

Russia, Primorskiy Kray, Bakalin, P-76-5-05 (KPABG)

Norway, Spitsbergen, Konstantinova K 121-5-06 (KPABG)

Russia, Murmansk Prov., Bakalin, 3-1-02 (KPABG)

Russia, Caucasus, Karachayevo-Cherkessian Rep.,

Konstantinova, K 510-1-05 (KPABG)

GQ220762 GQ220778

GQ220751 GQ220767

EU791668 EU791791

EU791704 EU791825

DQ875078 DQ875116

Russia, Kamchatka Prov., Bakalin, K 20-2-04 (KPABG)

EF065685 EF065692

DQ875079 EF065693

Russia, Murmansk Prov., E. Borovichev, 22.VII.04 (KPABG) EF090623 EF090629

Russia, Murmansk Prov., Bakalin, 4.VI.1998 (KPABG)

AF519195 DQ875113

Russia, Commander Island, Bakalin, K-41-5-04 (KPABG)

EF090624 DQ875115

Norway, Spitsbergen, Konstantinova, K 91-4-06 (KPABG)

EU791679 EU791796

Russia, Kemerovo Prov., Konstantinova, 90-7-00 (KPABG)

DQ875077 DQ875114

Russia, Yakutia, Zolotov \& Sofronova, 13.VII.2003 (KPABG)

EU791686 EU791805

Russia, Krasnoyarskiy Kray, Fedosov, 107960 (KPABG)

EU791687 EU791806

Russia, Kemerovo Prov., Konstantinova, 61-1-00 (KPABG)

Russia, Murmansk Prov., Konstantinova, 21-3b-96(KPABG)

Russia, Murmansk Prov., Konstantinova, 315-8-00 (KPABG)

USA, Washington, Konstantinova, A 22-6a-95 (KPABG)

Russia, Buryatia, Konstantinova, $\mathrm{HRE}^{1} 49$ (KPABG)

Belgium, Konstantinova, 2-20-3-99 (KPABG)

USA, Washington, Konstantinova, A10-4a-95 (KPABG)

Germany, Konstantinova, 28.VIII.86

Russia, Murmansk Prov., Konstantinova, 354-5b-00(KPABG)

Russia, Murmansk Prov., Konstantinova, 358-3-00 (KPABG)

Russia, Buryatia, Konstantinova, 24-1-02 (KPABG)
EU791690 EU791809

EU791688 EU791807

EU791689 EU791808

EU791655 EU791764

EU791633 EU791741

EU791627 EU791735

EU791657 EU791767

EU791648 EU791757

EU791646 EU791755

EU791628 EU791736

EU791643 EU791752 
Taxon

S. ferruginea (Lehm. \& Lindenb.)

Gottsche, Lindenb. \& Nees

S. glaucocephala (Taylor) Austin

S. gymnostomophila Kaal.

S. helvetica Gottsche 1

S. helvetica Gottsche 2

S. hyperborea Jörg. 1

S. hyperborea Jörg. 2

S. irrigua (Nees) Nees 1

S. irrigua (Nees) Nees 2

S. kaurinii Ryan

S. mucronata $\mathrm{H}$. Buch 1

S. mucronata $\mathrm{H}$. Buch 2

S. nemorea (L.) Grolle

S. obcordata (Berggr.) S.W.Arnell

S. paludicola Loeske et Müll. Frib.

S. paludosa (Müll.Frib.) Müll. Frib. 1

S. paludosa (Müll.Frib.) Müll. Frib. 2

S. rufidula Warnst.

S. simmonsii Bryhn et Kaal.

S. sphaerifera H.Buch et Tuom.

S. spitsbergensis (Lindb.) Müll. Frib. 1

S. spitsbergensis (Lindb.) Müll. Frib. 2

S. subalpina (Nees ex Lindenb.) Dumort. 1

S. subalpina (Nees ex Lindenb.) Dumort. 2

S. tundrae (Arnell) H. Buch

S. uliginosa (Sw. ex Lindenb.) Dumort.

S. umbrosa (Schrad.) Dumort.

S. undulata (L.) Dumort

S. verrucosa Heeg

Schistochilopsis incisa (Schrad.)

Konstantinova 1

S. incisa (Schrad.) Konstantinova 2

S. grandiretis (Lindb. Ex Kaal.) Schiffn.

S. opacifolia (Meyl.) Konstant. 1

S. opacifolia (Meyl.) Konstant. 2

Schljakovia kunzeana (Hübener)

Konstant. \&Vilnet 1

S. kunzeana (Hübener) Konstant. \&Vilnet 2

Schljakovianthus quadrilobus (Lindb.)

Konstant. \&Vilnet 1

S. quadrilobus (Lindb.) Konstant. \&Vilnet 2

Solenostoma confertissimum (Nees) Schljakov

S. fusiformis (Steph.)Steph.

S. handelii (Schiffn.) Müll. Frib.

S. pseudopyriflorum Bakalin \&Vilnet

S. $s p$.

Sphenolobus minutus (Schreb.) Berggr. 1

S. minutus (Schreb.) Berggr. 2
Herbarium voucher

Accession no.

trnL ITS

India, Sikkim, D. Long, 22492 (KPABG)

Russia, Buryatia, Konstantinova, 64-5-02 (KPABG)

AF519193 EU791766

Russia, Murmansk Prov., Konstantinova, 13-1-98(KPABG) EU791649 EU791758

Russia, Caucasus, Karachayevo-Cherkessian Rep.,

Konstantinova K414-1-05 (KPABG)

EU791620 EU791728

Russia, Caucasus, Karachayevo-Cherkessian Rep.,

Konstantinova, 488-3-05 (KPABG)

Russia, Murmansk Prov., Konstantinova, 509-3a-04 (KPABG)

Russia, Yakutia, Bakalin, 1-10-00 (KPABG)

EU791619 EU791727

EU791635 EU791744

EU791636 EU791745

Russia,Permskiy Kray, Konstantinova, K 372-5-04(KPABG) EU791624 EU791732

Russia, Murmansk Prov., Konstantinova, 219-4-02(KPABG) EU791625 EU791733

Russia, Chita Prov., Bakalin, 11-1-00 (KPABG)

Russia, Tuva Rep., Bakalin, 100854 (KPABG)

Russia, Karelia, 43-8-01 (KPABG)

Belgium, Konstantinova, 1-20-9-99(KPABG)

Norway, Spitsbergen, Konstantinova, 123-1-04 (KPABG)

Russia, Karelia, Bakalin, 11.VIII.1997

Russia, Permskiy Kray, Konstantinova, K316-2-04 (KPABG)

Russia, Kemerovo Prov., Konstantinova, 4-3-00 (KPABG)

Russia, Yakutia, Bakalin, 35-3-00 (KPABG)

Russia, Murmansk Prov., Konstantinova, 45-9-98 (KPABG)

Russia, Buryatia, Konstantinova, 92-2-01(KPABG)

Russia, Buryatia, Konstantinova, 121-6-02 (KPABG)

Norway, Spitsbergen, Konstantinova, K 90-2-06 (KPABG)

Russia, Permskiy Kray, Konstantinova, K379-04 (KPABG)

Russia, Buryatia, Konstantinova, 136-4-01 (KPABG)

Norway, Spitsbergen, Konstantinova, 140-1-04 (KPABG)

Russia, Murmansk Prov., Bakalin, 25-7-01 (KPABG)

Russia, Komi Rep., M. Dulin, MD 139-1-99 (KPABG)

Russia, Murmansk Prov., Konstantinova, 208-2-02 (KPABG)

Russia, Caucasus, Karachayevo-Cherkessian Rep.,

Konstantinova, 609/6-05 (KPABG)

Russia, Caucasus, Karachayevo-Cherkessian Rep.,

Konstantinova, K411-1-05 (KPABG)

Russia, Murmansk Prov., Konstantinova,187-1-02 (KPABG)

Russia, Kamchatka Prov., Bakalin, 99-5-01-VB (KPABG)

Norway, Spitsbergen, Konstantinova, K-43-2-05 (KPABG)

Russia, Caucasus, Karachayevo-Cherkessian Rep.,

Konstantinova, K 468-6b-05 (KPABG)

EU791650 EU791759

EU791629 EU791737

EU791630 EU791738

EU791645 EU791754

EU791626 EU791734

AF519196 EU791743

EU791639 EU791748

EU791638 EU791747

EU791637 EU791746

EU791653 EU791762

EU791656 EU791765

EU791651 EU791760

EU791652 EU791761

EU791641 EU791750

EU791640 EU791749

EU791634 EU791725

\& EU791742

EU791631 EU791739

EU791632 EU791740

EU791642 EU791751

EU791654 EU791763

EF065689 -

DQ875083 -

DQ875081 DQ875122

\& DQ875120

DQ875082 DQ875121

EF065688 GQ220784

Russia, Kamchatka Prov., Bakalin, K 56-9-02 VB (KPABG) EU722350 EU727545

Russia, Murmansk Prov., Konstantinova, 181-02 (KPABG)

Russia, Tuva Rep., Otnyukova, Bakalin, 100805 (KPABG)

Russia, Komi Rep., Dulin, 101302 (KPABG)

Russia, Caucasus, Karachayevo-Cherkessian Rep.,

Konstantinova, K 459-8a-05 (KPABG)

Russia, Kamchatka Prov., Bakalin, HRE 42 (KPABG)

Japan, M. Itouga, Bryophytes of Asia 194 (KPABG)

Russia, Buryatia, Konstantinova, 30-2-01 (KPABG)

Russia, Caucasus, Karachayevo-Cherkessian Rep.,

Konstantinova, K 419-05 (KPABG)

Russia, Karelia, Bakalin, 24.VII.1998 (KPABG)

Norway, Spitsbergen, Konstantinova, K 68-1-06 (KPABG)
EU722349 EU727544

EU791666 EU791786 EU791665 EU791785

GQ220758 GQ220774 GQ220757 GQ220773 GQ220756 GQ220772 GQ220759 GQ220775

GQ220760 GQ220776

AY327766 EU791790

EU791667 EU791789 
Taxon

S. saxicola (Schrad.) Steph.

Tetralophozia filiformis (Steph.) Urmi

T. setiformis (Ehrh.) Schljakov

Tritomaria exsecta (Schhmidel) Loeske

T. exsectiformis (Breidl.) Loeske

T. quinquedentata (Huds.) H. Buch

T. quinquedentata

f. gracilis (Jens.) R.M. Schust. 1

T. quinquedentata

f. gracilis (Jens.) R.M. Schust. 2

Tritomaria scitula (Tayl.) Jørg.

\section{Herbarium voucher}

Russia, Buryatia, Konstantinova , 123-3-02 (KPABG)

Russia, Buryatia, Konstantinova, 13-24-01 (KPABG)

Russia, Buryatia, Konstantinova, 123-2-02 (KPABG)

Russia, Nizhny Novgorod Prov.,

$$
\text { Konstantinova, 103-1-03 (KPABG) }
$$

Russia, Buryatia, Konstantinova, 83-4-01 (KPABG)

Russia, Karelia, Bakalin, 02.VII.1997 (KPABG)

Norway, Spitsbergen, Konstantinova, K 118-2-06(KPABG)

Norway, Spitsbergen, Konstantinova, K 72-2-06 (KPABG)

Russia, Komi Rep., Dulin, G101301 (KPABG)
Accession no.

$\operatorname{trn} \mathrm{L}$

ITS

DQ875086 DQ875124

EU791669 EU791792

EU791670 EU791793

EU791682 EU791800

EU791683 EU791801

AY327786 EU791804

EU791684 EU791802

EU791685 EU791803

EU791681 EU791799 